\title{
COMPARISON OF PHENOLIC EXTRACTS OBTAINED OF PINUS RADIATA BARK FROM PULP AND PAPER INDUSTRY AND SAWMILL INDUSTRY
}

\author{
Estrella Aspé $e^{1}$, Katherina Fernández ${ }^{1}$
}

\begin{abstract}
Pinus radiata barks obtained from tress of different ages, as subproduct of pulp and paper (trees less than 10 years) and sawmill (trees between 20 to 25 years) industries, were used to produce extracts containing phenolic compounds. A factorial design $2^{3}$ was used to evaluate the influence of the variables temperature $\left(25-35^{\circ} \mathrm{C}\right)$, solvent type (acetone - ethanol) and extraction time (1-12 h). The extracts were compared in their extraction yield (\%), total phenols (by FolinCiocalteau), and radical scavenging activity (by DPPH). The extract obtained from old trunks presented a higher extraction yield than from young trees. The highest yield value was $2.56 \%$, which was obtained using acetone as solvent for $12 \mathrm{~h}$ and $35^{\circ} \mathrm{C}$. The highest concentration of phenol $(5.84 \pm 0.18 \mathrm{~g} \mathrm{CE}$ $\mathrm{g}$ extract $\left.{ }^{-1}\right)$, and scavenging activity $(\mathrm{IP}=86.1 \pm 4.4 \%$ ) were also obtained for this type of extract. The extraction duration was the variable that most influenced the parameters studied. The bark's radical scavenging power was greater than BHT (40\%) and slightly lower than ascorbic acid (92\%), common commercial antioxidants.
\end{abstract}

Keywords: Antioxidants; bark; Pinus radiata; tannins.

\section{INTRODUCTION}

The forest industry is an important productive sector based on renewable natural resources. As a result, considerable amounts of products are discarded each year, mainly from sawmill and cellulose industries as processing byproducts that include sawdust, wood chips and barks (Egaña 1999). Statistics revealed that the total amount of wood residues produced during 2000-2001, from the main exported countries, exceeded 6 million of cubic meters (EFI 2003). Although, the statistics do not clearly indicate their final destinations, most of the byproducts were used for particle boards or energy purposes (Hillring 2006). These recycled products have low economic value, even when a number of bioactive compounds have been identified in bark (Balaban and Ucar 2001, Nunes et al. 1999). Therefore, there exists a great potential for the forest industry to convert and utilize more of these byproducts, transforming them into high value products.

In Chile, $67.8 \%$ of wood production is from Pinus radiata; of this percentage, $32 \%$ correspond to pulp and paper production, $40 \%$ to sawmill wood and the rest to others uses. The length, diameter and age of the trees used for cellulose and sawmill wood production are different (Maldonado 2008), and consequently the properties and characteristics of their bark should differ. 
Koreans and Spanish researchers have reported the extraction of phenols from Pinus radiata bark and their potential use in the food industries for to their antioxidant properties (Jerez et al. 2006; Jerez et al. 2007a; Jerez et al. 2007b; Raghavendra et al. 2007). Also, antioxidant effects have been described for extracts from Pinus maritime bark (Pycnogenol $\left.{ }^{\circledR}\right)$ (Packer et al. 1999) and from Pinus pinaster (Jerez et al. 2007a) under diverse extraction conditions.

Barks extract is a natural resource that could replace synthetic antioxidants as butylatedhydroxyanisole (BHA) and butylatedhydroxytoluene (BHT), which are suspected of being responsible for liver damage and carcinogenesis in laboratory animals (Nishioka et al. 2007). Recently, evidence has demonstrate that common pine (Pinus sylvetris L.) bark extracts (SokolLetowska et al. 2007) and mangrove Rhizophoraapiculata bark extracts (Rahim et al. 2008) had an efficacy similar or superior to BHT, BHA and 6-Hydroxy-2,5,7,8-tetramethylchroman-2-carboxylic Acid (Trolox) at equivalent conditions.

The extraction protocols for solvent extraction should be an effective technique to obtain the highest yield extraction and adequate bioactives properties of the extract. These parameters are highly dependent on the extraction conditions, as evidenced for the different values obtained for extraction yield and radical scavenging activity from pine barks (Jerez et al. 2006; Palma et al. 2003; Raghavendra et al. 2007). Therefore, comparative studies to select the most appropriate extraction technique are necessary for each substrate. In a previous work, we produced pine bark extracts with one type of solvent, in a fixed time and temperature and they were chemically characterized, being the major constituent proanthocyanidins (Cortes et al. 2010). In this new investigation is seeking to evaluate the influence of some process variables on the extraction; mainly, in the yield extraction and the phenolic content of the extracts. In the future, others variables and technologies of extraction could be studied and the best results will be chemically fully characterized.

The goal of this research was to compare the yield of the extraction in percent, phenolic concentration, and radical scavenging activity of Pinus radiata barks extracts obtained from young trees and old trunks processing by Chilean forestry industries. A $2^{3}$ factorial design was performed for each substrate in order to determine the influence of the solvent, extraction time, and temperature on the phenolic extracts features. The bark radical scavenging capacity was also compared with typical commercial antioxidants (BHT and ascorbic acid).

\section{MATERIALS AND METHODS}

\section{Bark Samples}

Two bark types were used: one from the cellulose industry (young bark) and the other from the sawmill industry (old bark). The young bark was obtained from Arauco Cellulose plant, Arauco, VIII Region, Chile; the age of trees was less than 10 years. The old bark was obtained from Laurel Sawmill, Santa Juana, VIII Region, Chile; the age of trees was between 20 to 25 years. Both samples were dried at room temperature, grounded with a knife mill and sieved to select the particles between 1 and $2 \mathrm{~mm}$. The bark's initial humidity was constant during the experiments $(14 \pm 1 \%)$ and it was determined by using the weight of bark before and after oven dried at $105^{\circ} \mathrm{C}$ for $2 \mathrm{~h}$. The bark density for both samples was also determined using a pycnometer.

\section{Experimental Design}

Two full factorial $2^{3}$ experimental designs (Box 2000) were developed to evaluate the effect of the temperature $(\mathrm{T})$, extraction duration/time $(\mathrm{t})$ and solvent type $(\mathrm{S})$ in the extracts from barks of young and old trees. Temperature values were $25^{\circ} \mathrm{C}$ and $35^{\circ} \mathrm{C}$, extraction duration time $1 \mathrm{~h}$ and $12 \mathrm{~h}$, and the solvents were acetone and ethanol from Merck (Darmstadt, Germany). Statgraphics 
Plus for Windows 4.0 (Herndon, VA) was used for statistical analyses of experimental design. The variables were codified in the way that their value ranged between +1 and -1 . Acetone and the highest values of the variables $\left(35^{\circ} \mathrm{C}\right.$ and $\left.12 \mathrm{~h}\right)$ were codified as +1 ; ethanol and the lowest values of the variables $\left(25^{\circ} \mathrm{C}\right.$ and $\left.1 \mathrm{~h}\right)$ were codified as -1 for the computational analysis with Statgraphics A central point in triplicate was codified as 0 and represents a central point of variables. The liquidsolid ratio was maintained in 1:5 (w/v).

The data were adjusted to a response surface $\mathrm{R}$

$$
R=a_{o}+a_{1} t+a_{2} T+a_{3} S+a_{12} t T+a_{13} t S+a_{23} T S
$$

where $a_{0}$ is the value of the objective function in the central point conditions, $a_{1}, a_{2}, a_{3}$ represent the principal effects associated with each variable and the others represent the crossed effects among variables.

\section{Bark extraction}

The phenolic extraction from bark was performed in 500-mL capped flasks, where $50 \mathrm{~g}$ of ground pine bark (wet base) were solvent extracted at the temperature and for the time specified in the experimental design, in an orbital shaker G24 New Brunswick Scientific Co. Inc. (NJ, USA) with temperature control and at constant stirring rate $(200 \mathrm{rpm})$. Solids were separated by filtration, the solvent evaporated under reduced pressure and temperature $\left(\mathrm{T}<40^{\circ} \mathrm{C}\right)$, and the crude extracts reconstituted in $50 \mathrm{~mL}$ of bi-distillated water. The lipophilic compounds of the crude extract were removed with a triple hexane wash $(1: 1 \% \mathrm{w} / \mathrm{w})$. The aqueous extracts were freeze-dried and kept at $4^{\circ} \mathrm{C}$ for further analysis. The extraction yield (\%) was determined as the amount of extract recovered in mass compared with the initial amount of bark in dry base.

\section{Total phenols}

Total phenols were determined using the Folin-Ciocalteu method (Singleton and Rossi 1965). 2.5 $\mathrm{mL}$ of tenfold diluted Folin- Ciocalteu reagent (Sigma, St Louis,MO, USA), $2 \mathrm{~mL}$ of $7.5 \%$ sodium carbonate(Sigma, St Louis, MO, USA), and $0.5 \mathrm{~mL}$ of phenolic extract $(0.15 \mathrm{~g} / \mathrm{L})$ were mixed well. After heating the sample for $15 \mathrm{~min}$ to $45^{\circ} \mathrm{C}$, the absorbance was measured at $765 \mathrm{~nm}$ (Shimadzu UV-1203, Japan). A mixture of water and reagents was used as blank. A calibration curve was built using $(+)$-catechin as standard to quantifying of catechin equivalents $(\mathrm{mg} \mathrm{CE} / \mathrm{L})$ and normalized by the amount of extract obtained in each experimental point to $\mathrm{mg} \mathrm{CE} / \mathrm{g}$ extract.

\section{Radical scavenging activity}

To determine the radical scavenging ability of the extracts, a 2,2-Diphenyil-picrylhydrazyl (DPPH) (Sigma, St Louis, MO, USA) radical assay was performed (Brandwilliams et al. 1995; Jerez et al. 2006). A volume of $980 \mu \mathrm{L}$ of $6.110^{-5} \mathrm{M}$. DPPH in methanol solution was used. There action was started by adding $20 \mu \mathrm{L}$ of methanolic crude extract $(0.15 \mathrm{~g} / \mathrm{L})$. The bleaching of DPPH ${ }^{*}$ was followed at $515 \mathrm{~nm}$ until that absorbance remained unchanged $(15 \mathrm{~min})$ in the dark and at room temperature. The radical scavenging activity was expressed as the inhibition percentage (IP) of the $\mathrm{DPPH}^{*}$ radical and was calculated as:

$$
\operatorname{IP}(\%)=\left(1-\frac{\text { absorbance }_{\mathrm{t}=\text { equilibrium }}}{\text { absorbance }_{\mathrm{t}=0}}\right) \cdot 100
$$

The performance of phenolic extract was also compared with commercial antioxidants, butylated hydroxytoluene (BHT) and acid ascorbic, under the same concentration $(0.15 \mathrm{~g} / \mathrm{L})$. 


\section{Statistical analysis}

The samples were analyzed in triplicate and the data presented as mean \pm standard using the Statgraphics Plus for Windows 4.0 (Herndon, VA).

\section{RESULTS AND DISCUSSION}

In Chile, tree diameter and length determine whether it will be used in the sawmill industry or in pulp and paper industry. Trees with a minimum width of $18 \mathrm{~cm}$ and a length of $3.2 \mathrm{~m}$ with ages from 20 to 25 years are used in sawmills to produce wood, while trees with a diameter minimum of $8 \mathrm{~cm}$ and $2.44 \mathrm{~m}$ in length (produced during the trimming, thinning and pruning stages) older than five years are used to produce cellulose (CMPC 2008). These differences in raw material suggest variations in the bark's characteristics and composition in physical and chemical terms, as will be established in the next paragraphs.

The physical characteristics of bark obtained from pulp and paper industry and bark from sawmill industry were different. The bark from pulp and paper industry was thinner and ductile with a maximum thickness of $1 \mathrm{~cm}$, while the bark from sawmill industry was thicker and rigid with a maximum thickness of $3 \mathrm{~cm}$. These differences were also represented in their densities. After grinding, young bark density was $580 \mathrm{~kg} / \mathrm{m}^{3}$ and it was lower than old bark density, close to $890 \mathrm{~kg} / \mathrm{m}^{3}$.

\section{Yield extraction of bark from young and old trees}

From the data set of experimental design, the amount of extract obtained in relation to the amount of bark processed, for both barks (dry base) is presented table 1 and table 2, respectively. The old bark presented a higher yield (10\% in average) than young bark yield. The analysis of each set of experiments shows that the yield was always higher for 12 hours of extraction, with an average difference of $15 \%$ with respect to $1 \mathrm{~h}$. The highest yield of $2.56 \%$ was obtained for old bark using acetone as a solvent during $12 \mathrm{~h}$ extraction at $35^{\circ} \mathrm{C}$.

Table 1. Levels of total phenols, tannins and anti-radical activity for bark extracts from old trees based in a design factorial.

\begin{tabular}{|c|c|c|c|c|c|c|}
\hline Experiment & $\begin{array}{c}\text { Temperature } \\
\left({ }^{\circ} \mathrm{C}\right)\end{array}$ & $\begin{array}{c}\text { Solvent } \\
\text { type }\end{array}$ & $\begin{array}{c}\text { Time } \\
\text { (h) }\end{array}$ & $\begin{array}{c}\text { Yield } \\
(\%)\end{array}$ & $\begin{array}{c}\text { Total } \\
\text { phenols } \\
\left(\text { g CE}^{*} \cdot g\right. \\
\left.\text { extract }^{-1}\right)\end{array}$ & $\begin{array}{c}\text { Inhibition } \\
\text { Percentage } \\
(\%)\end{array}$ \\
\hline 1 & 25 & Acetone & 12 & 2.49 & $5.34 \pm 0.01$ & $82.9 \pm 5.8$ \\
\hline 2 & 35 & Acetone & 12 & 2.56 & $5.44 \pm 0.04$ & $79.1 \pm 4.7$ \\
\hline 3 & 25 & Ethanol & 12 & 2.46 & $4.90 \pm 0.13$ & $73.7 \pm 4.7$ \\
\hline 4 & 35 & Ethanol & 12 & 2.43 & $5.46 \pm 0.08$ & $80.4 \pm 4.3$ \\
\hline 5 & 25 & Acetone & 1 & 2.11 & $5.67 \pm 0.03$ & $83.4 \pm 3.8$ \\
\hline 6 & 35 & Acetone & 1 & 2.01 & $5.84 \pm 0.18$ & $86.1 \pm 4.4$ \\
\hline 7 & 25 & Ethanol & 1 & 2.10 & $5.63 \pm 0.04$ & $83.4 \pm 1.4$ \\
\hline 8 & 35 & Ethanol & 1 & 2.21 & $5.44 \pm 0.16$ & $83.2 \pm 1.3$ \\
\hline 9 & 27.5 & Acetone & 5.5 & 2.23 & 5.68 & 83.2 \\
\hline 10 & 27.5 & Acetone & 5.5 & 2.37 & 5.70 & 82.7 \\
\hline 11 & 27.5 & Acetone & 5.5 & 2.28 & 5.67 & 80.5 \\
\hline
\end{tabular}

*CE: Catechin equivalent 
The maximum yield obtained in this study was low and similar to other reported for Pinus radiata bark (2.0\%); although, with different operating conditions (extraction time $24 \mathrm{~h}$ and, solvent Met $\mathrm{OH} / \mathrm{H}_{2} \mathrm{O}(7: 3 \% \mathrm{v} / \mathrm{v})$ ) (Diouf et al. 2006). Using more aggressive conditions $\left(\mathrm{NaOH} / \mathrm{H}_{2} \mathrm{O} 1 \%\right.$, $\left.100^{\circ} \mathrm{C}\right), \mathrm{Ku}$ and Mun (2007) increased ten times the yield. This difference could be explained by a probable higher lignin extraction generated by the $\mathrm{NaOH}$ addition and higher temperature. Also, by means of successive extractions with hexane, ethyl alcohol and hot water yielded the highest total extractives for pine 43.8\% (Hafizoglu et al. 2002). The differences with these authors are that in this work, the experiments were designed to be performed at a reduced temperature, with a solvent that can be easily recovered and that will preserve the extract's characteristics.

Table 2. Levels of total phenols, tannins and anti-radical activity for bark extracts from young trees based in a design factorial.

\begin{tabular}{ccccccc}
\hline Experiment & $\begin{array}{c}\text { Temperature } \\
\left({ }^{\circ} \mathbf{C}\right)\end{array}$ & $\begin{array}{c}\text { Solvent } \\
\text { type }\end{array}$ & $\begin{array}{c}\text { Time } \\
(\mathbf{h})\end{array}$ & $\begin{array}{c}\text { Yield } \\
(\boldsymbol{\%})\end{array}$ & $\begin{array}{c}\text { Total } \\
\text { phenols } \\
\left(\mathbf{g ~ C E}^{*} \cdot \mathbf{g}\right. \\
\left.\mathbf{e x t r a c t}^{-\mathbf{1}}\right)\end{array}$ & $\begin{array}{c}\text { Inhibition } \\
\text { Percentage } \\
(\boldsymbol{\%})\end{array}$ \\
\hline 1 & & & & & \\
2 & 25 & Acetone & 12 & 2.12 & $5.49 \pm 0.01$ & $79.4 \pm 3.5$ \\
3 & 35 & Acetone & 12 & 2.13 & $5.23 \pm 0.01$ & $79.9 \pm 4.6$ \\
4 & 25 & Ethanol & 12 & 2.12 & $4.93 \pm 0.14$ & $77.7 \pm 3.6$ \\
5 & 35 & Ethanol & 12 & 2.16 & $5.08 \pm 0.13$ & $78.5 \pm 3.0$ \\
6 & 25 & Acetone & 1 & 1.91 & $5.20 \pm 0.03$ & $84.2 \pm 3.0$ \\
7 & 25 & Acetone & 1 & 1.92 & $5.57 \pm 0.02$ & $85.9 \pm 4.0$ \\
8 & 25 & Ethanol & 1 & 1.94 & $5.25 \pm 0.04$ & $79.0 \pm 3.5$ \\
9 & 35 & Ethanol & 1 & 2.08 & $5.27 \pm 0.22$ & $81.0 \pm 4.2$ \\
10 & 27.5 & Acetone & 5.5 & 2.18 & 5.15 & 81.4 \\
11 & 27.5 & Acetone & 5.5 & 2.11 & 5.33 & 81.0 \\
\hline
\end{tabular}

${ }^{*}$ CE: Catechin equivalent

\section{Characterization of the extracts}

The major constituents in pine bark extracts from Pinus pinaster and Pinus massoniana (Weber et al. 2007) and Pinus radiata (Cortes et al. 2010) are proanthocyanidins. However, given the complexity of their analysis, the composition and properties of the extracts were analyzed according to the total phenol, and radical scavenging activity as indicators of the effect of change the extraction variables.

The characteristics for both barks are presented also in table 1 and table 2, respectively. A lower amount of total phenols and radical scavenging activity were observed in young bark than in old bark. These differences could be associated to a higher accumulation of extractives in aged trees. Changes in the chemical composition of the tree as consequence of the ageing had also been reported in others species such as maritime pine (Esteves et al. 2005), Eucalyptus globulus (Miranda and Pereira 2002) and larch (Gierlinger and Wimmer 2004).

The highest values of total phenols ( $5.84 \pm 0.18 \mathrm{~g} \mathrm{CE} / \mathrm{g}$ extract), and radical scavenging capacity $(86.1 \pm 4.4 \%)$ were obtained for the operation condition of $1 \mathrm{~h}$, acetone, $35^{\circ} \mathrm{C}$. Considering the differences in the extraction method, quantification methodology and data reports, it is difficult to compare our results with values obtained for Pinus radiata bark extracts in other studies. Still, total phenols content was found to be higher than the values obtained for other Pinus radiata analyzed with the same analytical method (Diouf et al. 2006, Raghavendra et al. 2007). 


\section{Factorial Analysis}

The factorial analysis for the bark extracts from old trees showed that the yield extraction is favored when the variables temperature, contact time and solvent are in their low level (Table 3). The concentration of phenols showed the same behavior, i.e. acetone as solvent, $25^{\circ} \mathrm{C}$ of temperature and a contact time of $1 \mathrm{~h}$ instead of $12 \mathrm{~h}$, would increase the phenol concentration. The inhibition percentage of the radicals by the extract, was not favored by prolong time of extraction in the interval of variation assayed. The analysis of bark extracts from young trees showed that the temperature was the most influencing variable for the yield and the inhibition percentage. An increase of phenols concentration was favored by the use of acetone as solvent. The models adjusted for the prediction of phenol composition of bark extracts from old trees presented a better adjusted (given by the correlation coefficient, $\mathrm{r}^{2}$ ) than the models for bark extracts from young trees.

Table 3. Models obtained from factorial design analysis for the barks analyzed

\begin{tabular}{ccc}
\hline Variable & Old bark model & Young bark model \\
\hline Yield & $\mathrm{Y}=3.52-0.14 \mathrm{~S}-0.15 \mathrm{t}-0.13 \mathrm{~S} \cdot \mathrm{t}$ & $\mathrm{Y}=2.06-0.85 \mathrm{t}$ \\
& $\left(\mathrm{r}^{2}=0.837 ; \mathrm{F}=2.27\right)$ & $\left(\mathrm{r}^{2}=0.807 ; \mathrm{F}=2.62\right)$ \\
Total phenol & $\mathrm{TP}=5.52-0.136 \mathrm{~S}-0.148 \mathrm{t}-0.128 \mathrm{~S} \cdot \mathrm{t}$ & $\mathrm{TP}=5.27-0.12 \mathrm{~S}$ \\
& $\left(\mathrm{r}^{2}=0.834 ; \mathrm{F}=2.23\right)$ & $\left(\mathrm{r}^{2}=0.612 ; \mathrm{F}=1.44\right)$ \\
\hline
\end{tabular}

Although, precautions were taken to avoid air or light oxidation, the phenols and tannin concentration seems to decline in a longer extraction time. A decrease in the amount phenols in others substrates, as in wine, also have been reported for a longer extraction period (Waterhouse 2002).

Several solvent systems have been used to extract antioxidants from bark. The solvent systems included hot water extraction (Raghavendra et al. 2007, Packer et al. 1999), alkaline extractions water $/ \mathrm{NaOH}(2 \%)$ (Fradinho et al. 2002), ethanol (Jerez et al. 2006), acetone/water $(70: 30 \% \mathrm{v} / \mathrm{v})$ (Rahim et al. 2008), ethanol/toluene (68:32\%v/v) (Lomax et al. 1994), among others. The results of antioxidant activity alsohave been diverse: from $36.4 \%$ at $2 \mu \mathrm{g} / \mathrm{ml}$ until $98 \%$ at $100 \mu \mathrm{g} / \mathrm{ml}$ depending on the extract type and grade of purification (Raghavendra et al. 2007). Thus, a general criterion for establishing the best solvent to obtain a high antioxidant capacity is complex. Zhao and Hall (2008) assayed different solvent combinations to extract from raisins, finding that the antioxidant capacity was stronger for $80 \%-100 \%$ acetone; although, the extraction yield was lower than for other solvent systems (Zhao and Hall 2008). Also, lower molecular weight was present in the ethanol fraction from bearberry leaves, while higher molecular weight was present in the acetone fraction, which had more antioxidant than the ethanol fraction (Pegg et al. 2003). In our experience, a higher inhibition percentage of $\mathrm{DPP}^{\cdot}$ radical was obtained using acetone as extraction solvent in comparison with ethanol.

\section{Relationship among the phenol concentration and radical scavenging activity}

In old bark extract, a direct relationship between total phenols determined by the Folin-Ciocalteu assay and the radical scavenging activity was founded $\left(\mathrm{r}^{2}=0.820\right)$. Ku et al. (2007) in hot water bark extracts obtained from different Pines did not find a relationship between total phenols and anti-radical activity; we observed the same tendency in young barks extracts $\left(r^{2}=0.202\right)$.

The main difference of our study with others studies reported in the literature is that the solvents used $(100 \%$ acetone and ethanol) have different extraction capacity from that of hot water on the extract's composition: less impurities as sugars are expected and this difference can positively influence the Folin-Ciocalteu assay (Raghavendra et al. 2007). Also, the removal of waxes and lipids (with a triple hexane wash) helped mainly to the oxidation of phenols for the DPPH and Folin-Cicalteu assays. 
The radical scavenging activity of the extract was compared with commercial antioxidants, BHT and ascorbic acid. Bark extract performed twice as well in comparison with BHT, a chemical antioxidant used in the food industry ( $86 \%$ vs. $40 \%$, respectively) and similar to the ascorbic acid ( $86 \%$ vs $92 \%$ ), a recognized commercial antioxidant. Considering that the BHT and the ascorbic acid presented a purity superior to $99 \%$, and the phenolic extracts were not purified, this performance is an advantage from a process point of view.

Nevertheless, the yields obtained in this work are too low to be considered in an industrial process. In the future, it will be necessary to increase the extraction yield, using other extraction technologies or process conditions, while trying to preserve the high anti-radical activity found in the phenol extract of Pinus radiata. These results together with future results can be used to assess their potential use of the bark phenolic extracts in industrial applications.

\section{CONCLUSIONS}

This work shows that the tree age influences the physical and chemical characteristics of bark extracts. Young bark collected as sub-products of pulp and paper industry had lower extraction yields, phenol and radical scavenging activity than old bark collected as sub-products of sawmill industry. The factorial analysis shows that the extraction time is the significant variable and a reduced time will help to avoid the phenols oxidation. The acetone extraction increases the anti-radical activity than ethanol extraction. A direct relationship between phenols and the radical scavenging activity was observed. The radical scavenging activity of the extracts produced in this study had similar or better values than typical commercial antioxidants. The bark extracts from old trees have a higher potential to be a natural antioxidant than bark from young trees.

\section{ACKNOWLEDGEMENTS}

This investigation was supported by the project D.I. UdeC No. 208.096062-1.0 University of Concepción, Concepción, Chile. 


\section{REFERENCES}

Balaban, M.; Ucar, G. 2001. Extractives and structural components in wood and bark of endemic oak Quercus vulcanica Boiss. Holzforschung 55: 478-486.

Box, G.E.P.; Hunter, W. G.; Hunter J.S. 2000. Estadistica para investigadores. Introducción al diseño de experimentos, análisis de datos y construcción de modelos. Editorial Reverté, S.A., México.

Brandwilliams, W.; Cuvelier, M.E.; Berset, C. 1995. Use of a Free-Radical Method to Evaluate Antioxidant Activity. Food Sci. Tech. 28: 25-30.

Cortés, S.; Pulgar, H.; Sanhueza, V.; Aspé, E.; Fernández, K. 2010. Identification of proanthocyanidins extracted from Pinus radiata D. Don bark. Cien. Inv. Agr. 37: 15-25.

CMPC (2008). El árbol: destino de la madera. Compañía manufacturera de papeles y cartones. http://www.papelnet.cl/elarbol/8_destino_de_la_madera.html. (consulted 19 August 2011).

Diouf, P.N.; Merlin, A.; Perrin, D. 2006. Antioxidant properties of wood extracts and colour stability of woods. Ann. Forest Sci. 63: 525-534.

EFI. 2003. EFI/WFSE forest products trade flow database. European Forest Institute http:// www.efi.int/portal/virtual_library/databases/forest_products_trade_flow_database. (consulted 19 August 2011).

Egaña, P.P.C. 1999. Catastro y Evaluación de Recursos Vegetacionales Nativos de Chile. PROYECTO CONAF - CONAMA - BIRF, Santiago, Chile. Universidad Austral de Chile, Pontificia Universidad Católica y Universidad Católica de Temuco. 36-49.

Esteves, B.; Gominho, J.; Rodrigues, J. C.; Miranda, I.; Pereira, H. 2005. Pulping yield and delignification kinetics of heartwood and sapwood of maritime pine. J. Wood Chem. Tech. 25: 217-230.

Fradinho, D.M.; Neto, C.P.; Evtuguin, D.; Jorge, F.C.; Irle, M.A.; Gil, M.H.; de Jesus, J.P. 2002. Chemical characterization of bark and of alkaline bark extracts from maritime pine grown in Portugal. Ind. Crops Prod. 16: 23-32.

Gierlinger, N.; Wimmer, R. 2004. Radial distribution of heartwood extractives and lignin in mature European larch. Wood Fiber Sci. 36: 387-394

Hafizoglu, H.; Holmond, B.; Reunamen, M. 2002. Chemical composition of lipophilic and phenolic constituents of bark from Pinus nigra, Abies bornmulleriana, Castanea sativa. Holzforschung 56: 257-260.

Hillring, B. 2006. World trade in forest products and wood fuel. Biomass Bioener. 30: 815825.

Jerez, M.; Pinelo, M.; Sineiro, J.; Nunez, M.J. 2006. Influence of extraction conditions on phenolic yields from pine bark: assessment of procyanidins polymerization degree by thiolysis. Food Chem. 94: 406-414. 
Jerez, M.; Selga, A.; Sineiro, J.; Torres, J.L.; Nunez, M.J. 2007a. A comparison between bark extracts from Pinus pinaster and Pinus radiata: Antioxidant activity and procyanidin composition. Food Chem. 100: 439-444.

Jerez, M.; Tourino, S.; Sineiro, J.; Torres, J.L.; Nunez, M.J. 2007b. Procyanidins from pine bark: Relationships between structure, composition and antiradical activity. Food Chem. 104: 518-527.

Ku, Ch. S.; Mun, S.P. 2007. Characterization of proanthocyanidin in hot water extract isolated from Pinus radiata bark. Wood Sci Technol 41: 235-247.

Lomax, T.D.; Mackie, K.L.; Meder, R.; Croucher, M.; Burton, R.J. 1994. Steam Explosion of Pinus-Radiata Bark. J. Wood Chem.Tech. 14: 539-561.

Maldonado, J. 2008. Obtención de una antioxidante natural a partir de Pinus radiata D. Don. In: Tesis Ingeniería Química. Universidad de Concepción, Concepción.

Miranda, I.; Pereira, H. 2002. The variation of chemical composition and pulping yield with age and growth factors in young Eucalyptus globulus. Wood and Fiber Science 34: 140-145.

Nishioka, K.; Hidaka, T.; Nakamura, S.; Umemura, T.; Jitsuiki, D.; Soga, J.; Goto, C.; Chayama, K.; Yoshizumi, M.; Higashi, Y. 2007. Pycnogenol (R), French maritime pine bark extract, augments endothelium-dependent vasodilation in humans. Hypertens. Res. 30: 775-780.

Nunes, E.; Quilho, T.; Pereira, H. 1999. Anatomy and chemical composition of Pinus pinea L. bark. Ann. Forest Sci. 56: 479-484.

Packer, L.; Rimbach, G.; Virgili, F. 1999. Antioxidant activity and biologic properties of a procyanidin-rich extract from pine (Pinus maritima) bark, pycnogenol. Free Rad. Biol. Med. 27: 704-724.

Palma, G.; Freer, J.; Baeza, J. 2003. Removal of metal ions by modified Pinus radiata bark and tannins from water solutions. Wat. Res. 37: 4974-4980.

Pegg, R.B.; Amarowicz, R.; Naczk, M. 2003. Antioxidant activity of polyphenolics from bearberry (Arctostaphylos UVA-URSI L. Sprengel) leaf extract in meat systems. Abs. Papers Am. Chem. Soc. 226, 073-AGFD.

Raghavendra, M.P.; Kumar, P.R.; Prakash, V. 2007. Mechanism of inhibition of rice bran lipase by polyphenols - A case study with chlorogenic acid and caffeic acid. J. Food Sci. 72: E 412-419.

Rahim, A.A.; Rocca, E.; Steinmetz, J.; Kassim, M.J.; Ibrahim, M.S.; Osman, H. 2008. Antioxidant activities of mangrove Rhizophora apiculata bark extracts. Food Chem. 107: 200207.

Sokol-Letowska, A.; Oszmianski, J.; Wojdylo, A. 2007. Antioxidant activity of the phenolic compounds of hawthorn, pine and skullcap. Food Chem. 103: 853-859.

Waterhouse, A.L. 2002. Wine phenolics, Alcohol and Wine in Health and Disease. Annals of the New York Academy of Sciences 957: 21-36. 
Weber, H. A.; Hodges, A. E.; Guthrie, J. R.; O’Brien, B. M.; Robaugh, D.; Clark, A. P.; Harris, R. K.; Algaier, J. W.; Smith, C. S. 2007. Comparison of proanthocyanidins in commercial antioxidants: Grape seed and pine bark extracts. J.Agric.Food Chem. 55: 148-156.

Zhao, B.; Hall, C.A. 2008. Composition and antioxidant activity of raisin extracts obtained from various solvents Food Chem. 108: 511-518. 